\title{
Zebra Longwing, Heliconius charitonia (Linnaeus) (Insecta: Lepidoptera: Nymphalidae) ${ }^{1}$
}

Jaret C. Daniels ${ }^{2}$

\section{Introduction}

The zebra longwing, Heliconius charitonia (Linnaeus), was designated the state butterfly of Florida in 1996. A denizen of more forested settings, it frequents subtropical hammocks, forest margins, shrubby thickets, and adjacent open areas. It is a regular sight in many butterfly gardens and suburban yards and parks.

\section{Distribution}

The zebra longwing is a neotropical butterfly that occurs in extreme southern portions of the United States southward through Mexico, Central America and the West Indies to South America. Adults occasionally wander northward. It is locally common throughout peninsular Florida.

\section{Description}

Adults: Zebra longwings are medium-sized butterflies with elongated wings. They cannot be confused with any other Florida butterfly. Adults have a wingspan range of 72 to $100 \mathrm{~mm}$. The sexes are similar. The upper surface of the wings is black with several bold, narrow yellow stripes. The wings below have a similar pattern, but are paler in color and have several small red spots near the body.

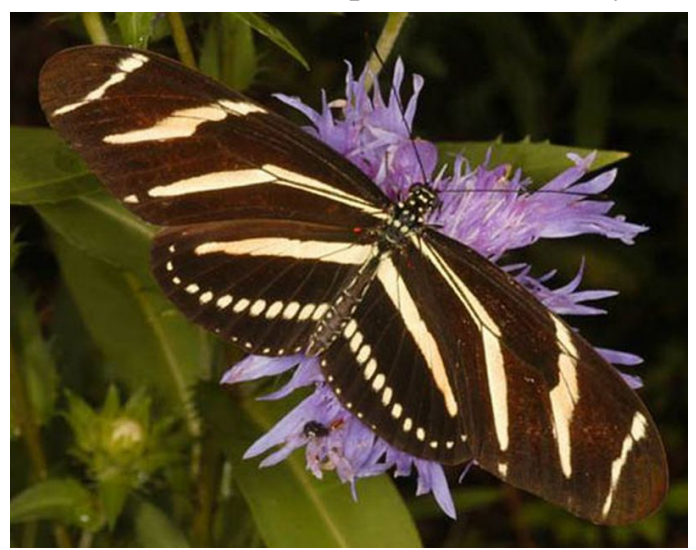

Figure 1. Adult zebra longwing butterfly, Heliconius charitonia (Linnaeus), with dorsal view of the wings. Credits: Jaret C. Daniels, University of Florida

Eggs: The yellow eggs are laid singly or in small clusters on new growth of the host plant.

Larvae: The mature larvae are white with black spots and numerous black branched spines.

1. This document is EENY-428, one of a series of Featured Creatures from the Entomology and Nematology Department, Florida Cooperative Extension Service, Institute of Food and Agricultural Sciences, University of Florida. Published: February 2009. This document is also available on Featured Creatures Website at http://creatures.ifas.ufl.edu. Please visit the EDIS Website at http://edis.ifas.ufl.edu. Additional information on these organisms, including many color photographs, is available at the Entomology and Nematology Department website at http://entnemdept.ifas.ufl.edu/.

2. Jaret C. Daniels, assistant professor, Entomology and Nematology Department, Institute of Food and Agricultural Sciences, University of Florida, Gainesville, FL 32611.

The Institute of Food and Agricultural Sciences (IFAS) is an Equal Opportunity Institution authorized to provide research, educational information and other services only to individuals and institutions that function with non-discrimination with respect to race, creed, color, religion, age, disability, sex, sexual orientation, marital status, national origin, political opinions or affiliations. U.S. Department of Agriculture, Cooperative Extension Service, University of Florida, IFAS, Florida A. \& M. University Cooperative Extension Program, and Boards of County Commissioners Cooperating. Millie Ferrer, Interim Dean 


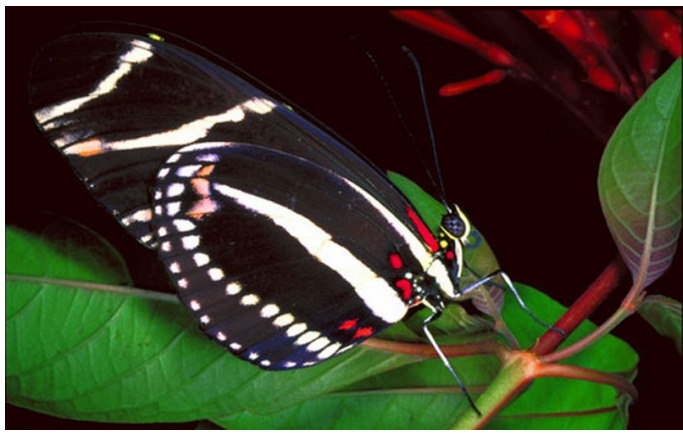

Figure 2. Adult zebra longwing butterfly, Heliconius charitonia (Linnaeus), with ventral view of the wings. Credits: Jaret C. Daniels, University of Florida

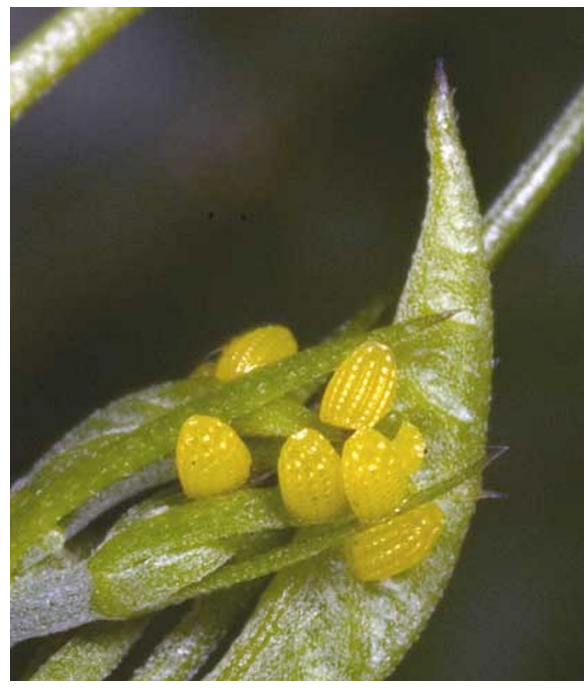

Figure 3. Eggs of the zebra longwing butterfly, Heliconius charitonia (Linnaeus), on maypop (purple passionflower), Passiflora incarnata L. (Passifloraceae). Credits: Jaret C. Daniels, University of Florida

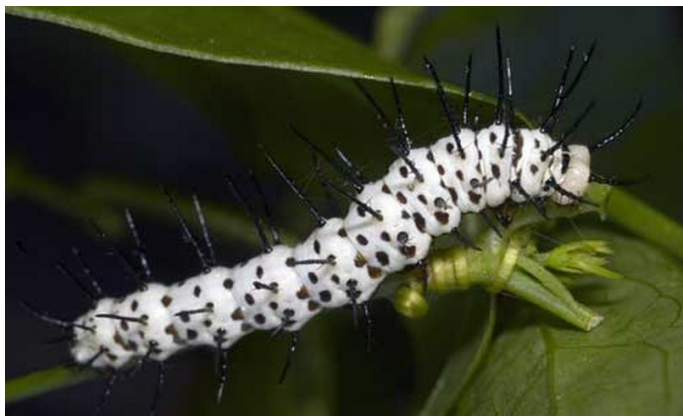

Figure 4. Mature larva of the zebra longwing butterfly, Heliconius charitonia (Linnaeus), on corkystem passionflower, Passiflora suberosa L. (Passifloraceae). Credits: Jaret C. Daniels, University of Florida

Pupae: The pupae are brown and have two long flanges off the head.

\section{Life Cycle}

The zebra longwing produces multiple generations each year. Adults may be found in all months of the year throughout much of central and southern portions of Florida. Adults have slow, relaxed flight. Females lay the small yellow eggs singly or in small clusters on terminal leaves and trendrils of the host plants.

Adult zebra longwing butterflies feed on both flower nectar and pollen. The additional nutrients from the pollen enable individuals to survive for several months, far exceeding the normal two to four week adult life span of most other butterflies. Adult individuals often form small communal roosts at night.

\section{Hosts}

Common hosts are purple passionflower, Passiflora incarnata L.; corkystem passionflower, Passiflora suberosa L.; yellow passionflower Passiflora lutea L.; and several other passionflower vines.

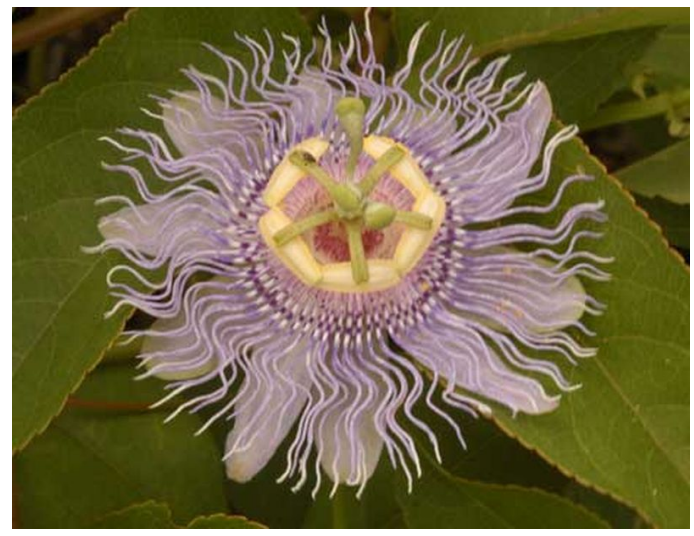

Figure 5. Purple passionflower, Passiflora incarnata L. (Passifloracaea), a host of the zebra longwing butterfly, Heliconius charitonia (Linneaus). Credits: Jaret C. Daniels, University of Florida

\section{Selected References}

Cech R, Tudor G. Butterflies of the East Coast: An Observer's Guide. 2005. Princeton University Press, Princeton, NJ. 345 pp.

Daniels JC. Butterflies of Florida Field Guide. 2003. Adventure Publications, Cambridge, MN. 250 pp. 
Daniels JC. 2000. Butterflies 1: Butterflies of the Southeast. UF/IFAS. Card Set. SP 273.

Kimball CP. 1965. The Lepidoptera of Florida; an annotated checklist. Arthropods of Florida and Neighboring Land Areas Vol. 1. Florida Department of Agriculture and Consumer Services, Division of Plant Industry. 363 pp.

Medley JC, Fasulo TR. (1998). Florida Butterfly Tutorials. University of Florida/IFAS. CD-ROM. SW 155 .

Minno MC, Butler JF, Hall DW. 2005. Florida Butterfly Caterpillars and Their Host Plants. University Press of Florida, Gainesville. 341 pp.

Minno MC, Emmel TC. 1993. Butterflies of the Florida Keys. Scientific Publishers, Gainesville. 168 pp. 